This is the submitted version of the following article: Abraham, J et al. Potential of the solid-state fermentation of soy fibre residues by native microbial populations for bench-scale alkaline portease production in Biochemical engineering journal (Ed. Elsevier), vol. 74 (May 2013), p. 1519, which has been published in final form at DOI 10.1016/j.bej.2013.02.008

(c) 2013. This manuscript version is made available under the "all rights reserved" license 


\title{
Potential of the solid-state fermentation of soy fibre residues by native microbial populations for bench-scale alkaline protease production
}

\author{
Juliana Abraham, Teresa Gea, Antoni Sánchez* \\ Department of Chemical Engineering \\ Universitat Autònoma de Barcelona \\ Cerdanyola del Vallès, 08193 Barcelona, Spain \\ *antoni.sanchez@uab.cat
}

\begin{abstract}
The production of alkaline proteases by solid-state fermentation (SSF) was evaluated. The effect of three agro-industrial residues was examined: coffee husk, hair waste from the tanning industry and soy fibre residues. Soy fibre presented the highest yield for protease production at the laboratory scale $\left(37^{\circ} \mathrm{C}, 100 \mathrm{~g}\right.$ samples $)$. Consequently, experiments with soy fibre (F) and soy fibre with $10 \%$ compost as an inoculum (FC) were performed for 14 days in 4.5 L bench-scale aerobic near-adiabatic reactors. The highest activity occurred under thermophilic conditions and a high respiration activity of $47331 \pm 1391 \mathrm{U} / \mathrm{g}$ dry matter for $\mathrm{F}$ and $18750 \pm 1596 \mathrm{U} / \mathrm{g}$ dry matter for FC, which are much higher values than those reported in other studies. Alkaline proteases showed maximum stability at $\mathrm{pH} 11$ and temperatures of $43.8^{\circ} \mathrm{C}(\mathrm{F})$ and $30^{\circ} \mathrm{C}(\mathrm{FC})$, which was determined by a full factorial experimental design. Storage assays demonstrated that $90 \%$ of enzyme activity was preserved for three months by lyophilising or freezing the samples at $-80^{\circ} \mathrm{C}$.
\end{abstract}

Keywords: Solid-state fermentation; alkaline protease; respiration activity; experimental design; bench scale production. 


\section{Introduction}

Solid-state fermentation (SSF) has been defined as the fermentation process that involves a solid matrix and is performed in the absence or near absence of free water [1]; however, the substrate must possess enough moisture to support the growth and metabolism of the microorganisms.

Among other applications, SSF can be used for producing enzymes using various substrates. Protease production by SSF under different process conditions, microorganisms and substrates has been reported [2,3]. However, most studies consist of lab-scale experiments using a few grams of substrate, a constant temperature, sterilised residues and specific microorganisms as the inoculum. Addressing SSF process scale-up under these conditions is a challenge because of the inherent difficulties of handling large quantities of solid substrate while avoiding biological contamination and problems related to mass and heat transfer that are associated with the solid processes. Few studies have been published on SSF that used a pilot scale [4]. The mathematical modelling of the process [5] has highlighted the effect of denaturalisation of the produced enzyme at pilot scale caused by an increase in temperature.

An alternative approach to overcome these constraints involves working with a microbial consortium under a dynamic temperature profile including a thermophilic range similar to that of a composting process. Additionally, when fermentation occurs at high temperatures, thermostable enzymes are produced as a microorganism's adaptation strategy $[6]$.

Amongst microbial proteases, alkaline proteases are used in an extensive range of applications in the detergent, food processing, pharmaceutical, leather dehairing and paper industries and in the processing of proteinaceous waste $[7,8]$. 
The objectives of this study are as follows: i) to screen which local agro-industrial wastes were suitable for producing proteases by SSF; ii) to define an easily scalable SSF process with the most suitable waste for protease production; and iii) to characterise the effect of $\mathrm{pH}$ and temperature on enzyme stability.

\section{Materials and Methods}

\subsection{Materials}

The materials used were soy fibre and coffee husk, which are final residues from the food industry, and hair waste from the tanning industry as a result of a chemical process in strong alkaline conditions (obtained from local industries in Barcelona, Spain). Table 1 shows the main characteristics of these residues. Wood chips were added to the materials in a 1:1 (w:w) ratio and acted as a bulking agent to provide the proper porosity [9].

Raw sludge (31.9\% dry matter $(\mathrm{DM}), 82.6 \%$ organic matter $(\mathrm{OM})$ and respiration index of $4.2 \mathrm{~g} \mathrm{O}_{2} \mathrm{~kg}^{-1} \mathrm{DM} \mathrm{h}^{-1}$ ) from a local wastewater treatment plant was used to inoculate the hair waste for the biodegradation, as described in previous studies (hair waste:raw sludge wet weight ratio of 1:2, [10]). Compost from a Barcelona composting plant $(83.1 \%$ DM, $76 \%$ $\mathrm{OM}$ and respiration index of $1.6 \mathrm{~g} \mathrm{O}_{2} \mathrm{~kg}^{-1} \mathrm{DM} \mathrm{h}^{-1}$ ) was used as an inoculum for the soy fibre in the $4.5 \mathrm{~L}$ reactors. This mixture was tested to compare protease production by SSF with the soy fibre native microorganisms and the soy fibre with a low-cost, widely used microbial consortium such as that of compost [11].

\subsection{Experiments}

\subsubsection{Lab scale}

To screen for a suitable protein-rich waste for protease production, preliminary SSF experiments were assayed in triplicate for five days at $37^{\circ} \mathrm{C}$ in $500 \mathrm{ml}$ Erlenmeyer flasks with $100 \mathrm{~g}$ of sample. The soy fibre, coffee husk and hair waste with raw sludge were mixed with 
bulking agent in a 1:1 (w:w) ratio and assayed without sterilisation. The dynamic respiration index (DRI) was determined [12]. The protease activities were analysed after incubation (five days).

\subsection{2. $4.5 \mathrm{~L}$ reactors}

Experiments were performed in duplicate for fourteen days in $4.5 \mathrm{~L}$ air-tight reactors, working under near-adiabatic conditions and with on-line temperature monitoring (Pt-100 sensors, Sensotran, Spain) and using a data acquisition system (MAC-3580, Desin, Spain) connected to a personal computer. Continuous aeration at a rate of $0.1 \mathrm{~L} / \mathrm{min}$ was provided to the reactors. The oxygen concentration in the exhaust gases was measured by means of an oxygen sensor (Crowcon's Xgard, United Kingdom) (Fig. 1). Previous studies determined that the gas flow in these $4.5 \mathrm{~L}$ reactors behaves similar to the plug flow with an axial dispersion model, according to the residence time distribution method [13]. Consequently, an oxygen concentration gradient can be estimated to determine whether the process is performing under aerobic conditions throughout the entire reactor.

The mixtures were prepared by mixing soy fibre and bulking agent in a wet weight ratio of $1: 1$ (experiment $F)$ and soy fibre, bulking agent (1:1,w:w) and $10 \%$ of compost (experiment FC). The final weight of the mixture was $1.250 \mathrm{~kg}$ for each reactor. The water content of the mixture was adjusted within the recommended values by adding tap water during the experiments as needed. Samples weighing $30 \mathrm{~g}$ were collected at $0,3,7,10$ and 14 days after manual homogenisation of the entire mass.

\subsection{Enzyme extraction}

Fermented solid medium was mixed thoroughly with $50 \mathrm{mM}$ HCl-Tris buffer, $\mathrm{pH} 8.10$ at a 1:5 (w:v) ratio for $45 \mathrm{~min}$, and the extract was separated by centrifugation at $5000 \mathrm{rpm}$ 
for $20 \mathrm{~min}$ and posterior filtration with a $0.45 \mu \mathrm{m}$ filter. The supernatant was used for the alkaline protease assay.

\subsection{Enzyme assay}

Alkaline protease activity was determined using a modified method described by Alef and Nannipieri [14]. A $1 \mathrm{ml}$ aliquot of the enzyme extract was added to $5 \mathrm{ml}$ of $2 \%$ casein solution and incubated at $50^{\circ} \mathrm{C}$ and $100 \mathrm{rpm}$ for 2 hours. One unit of alkaline protease activity was defined as $1 \mu \mathrm{g}$ of tyrosine released under the assay conditions.

\subsection{Effect of $p H$ and temperature on protease stability}

The effects of $\mathrm{pH}$ and temperature $(\mathrm{T})$ on alkaline protease stability were analysed by a 12 full factorial experimental design with three replicates at the centre (using the software package Sigmaplot version 10, Systat software Inc.). The temperature was fixed at 30, 50 and $70{ }^{\circ} \mathrm{C}$, and the $\mathrm{pH}$ was 5.00 (Tris- $\mathrm{HCl}, 1 \mathrm{M}$ ), 8.00 (Tris- $\mathrm{NaOH}, 1 \mathrm{M}$ ) and 11.00 (acetic acidsodium acetate, $1 \mathrm{M})$. The buffers were chosen to maintain the desired $\mathrm{pH}$ value during the entire experiment [8]. The objective function was the residual alkaline protease activity percentage after one hour of incubation.

\subsection{Alkaline protease conservation}

The enzyme extract was conserved at $4^{\circ} \mathrm{C},-20^{\circ} \mathrm{C},-80^{\circ} \mathrm{C}$ and after lyophilisation. These methods of conservation were evaluated to determine how long the extract could be preserved.

\subsection{Analytical Methods}

The water and organic matter content, total organic carbon (TOC), total nitrogen Kjeldahl (TNK), $\mathrm{pH}$ and electric conductivity (EC) were determined according to the standard procedures recommended by TMECC [15]. 


\section{Results and discussion}

\subsection{Screening materials for protease production}

A respirometric study was performed with the three residues to evaluate the biodegradability of each mixture and the best waste capable of protease production. The maximum enzyme production was observed with soy fibre. For instance, the protease production was $37244 \pm 1101 \mathrm{U} / \mathrm{g}$ DM for soy fibre, $10681 \pm 71 \mathrm{U} / \mathrm{g}$ DM for the coffee husk and $17011 \pm 2122 \mathrm{U} / \mathrm{g}$ DM for hair waste. The different levels of protease production could be caused by the chemical composition and biodegradability of the materials, the $\mathrm{pH}$ and $\mathrm{C} / \mathrm{N}$ ratio, and the different microbial populations that developed. The hair and coffee husk resulted in a lower DRI than soy fibre. Hair resulted in a high $\mathrm{pH}$ and an extremely high $\mathrm{N}$ content; however, this fraction might not correspond to an easily biodegradable fraction but, rather, to recalcitrant $\mathrm{C}$ and $\mathrm{N}$ chemical forms [16]. In addition to a high DRI, soy fibre has a considerable amino acid content and $\mathrm{N}$ availability [17]; therefore, it appears to be the best of the three assayed materials for producing proteases. As Pandey et al. reported [2], these results indicate that the protease production pattern varied with the type of residue. Based on these results, we selected the soy fibre for the bench-scale experiments.

\subsection{SSF trials in 4.5 L reactors with soy fibre}

Figure $2 \mathrm{a}$ and $2 \mathrm{~b}$ shows the temperature and $\mathrm{pH}$ profiles and the alkaline protease activity for one replicate of the F and FC experiments, respectively, in $4.5 \mathrm{~L}$ reactors. One replicate is shown as the difference in the temperature profile between replicates, which was below $5 \%$ in both cases (area below temperature curve was 456.71 and $476.63{ }^{\circ} \mathrm{C} \cdot$ day for $\mathrm{F}$ replicates, 501.16 and $519.69{ }^{\circ} \mathrm{C} \cdot$ day for $\mathrm{FC}$ replicates). The increase in temperature was caused by the biodegradation of organic matter. A secondary temperature increase was observed after homogenising the reactor contents when sampling at days 3, 7 and 10 . The 
results of the oxygen concentration gradient indicated that the reactors were fully aerobic during the entire process.

The profile of alkaline protease production is shown in Figures $2 \mathrm{a}$ and $2 \mathrm{~b}$. The highest protease activity coincided with the thermophilic phase, which was higher in experiment $\mathrm{F}$ $(47331 \pm 1391 \mathrm{U} / \mathrm{g} \mathrm{DM})$ than in FC $(18750 \pm 1596 \mathrm{U} / \mathrm{g} \mathrm{DM})$. These results suggest that the inoculation of different microorganisms from the compost did not increase the production of alkaline proteases and that the autochthonous microorganisms of soybean fibre are more efficient for protease production. The protease activity values were much higher than those reported in studies using other substrates $[18,19]$, suggesting that scaling-up the SSF process should not have a negative effect. The high yield was confirmed by preliminary experiments used to optimise the process conditions (bulking agent ratio, aeration requirements, etc.). Protease activity ranged from 42000 to $380546 \mathrm{UA} / \mathrm{g}$ for F experiments and from 30253 to $154337 \mathrm{UA} / \mathrm{g}$ for FC experiments.

The results showed that enzyme synthesis coincided with the increase in the temperature and $\mathrm{pH}$ that are inherent to an adiabatic biodegradation process of biodegradable organic matter [19]. This high production of alkaline protease under these experimental conditions indicates the possible thermostability of the enzymes and the alkalophilic nature of microbial strains, although further experiments were performed to validate this hypothesis (section 3.3). Additionally, the DRI of the final mixtures of $\mathrm{F}$ and $\mathrm{FC}$ were 0.92 and $0.58 \mathrm{~g} \mathrm{O}_{2}$ $\mathrm{kg}^{-1} \mathrm{DM} \mathrm{h}^{-1}$, respectively, indicating that the residues were fully stabilised after fourteen days of SSF, as reported in the composting field [17].

Finally, the results obtained from the conservation methods tested showed that the activity of the alkaline protease at $4^{\circ} \mathrm{C}$ and $-20^{\circ} \mathrm{C}$ was constant for only one week of storage. For the lyophilised samples, the activity was constant for one month, and at $-80^{\circ} \mathrm{C}$, the activities were stable (90\%) for at least three months (data not shown). Other studies have 
shown that proteases are unstable and that immobilisation is the only method for preserving activity for long-term storage [20].

\subsection{Effect of $p H$ and temperature on enzyme stability}

Figure 3 shows the response surface for residual activity as a function of temperature and $\mathrm{pH}$. Alkaline protease activity decreased after incubation for all the tested combinations. However, due to the high initial activity level, the enzyme extract still presents a high proteolytic potential. Equations (1) and (2) were obtained to describe enzyme stability (best fitting obtained from the normalised experimental values, statistically validated through $\mathrm{F}$ test) for F and FC, respectively:

Residual activity $(\%)=24.71+8.33 \mathrm{pH}-12.17 \mathrm{~T}-0.63 \mathrm{pH}^{2}-11.13 \mathrm{~T}^{2}-5.00 \mathrm{pHT}\left(\right.$ Eq. $\left.1, \mathrm{R}^{2}: 0.92\right)$ Residual activity $(\%)=27.63+12.67 \mathrm{pH}-11.50 \mathrm{~T}-1.63 \mathrm{pH}^{2}-6.88 \mathrm{~T}^{2}-8.23 \mathrm{pHT}\left(\right.$ Eq. $\left.2, \mathrm{R}^{2}: 0.95\right)$

The interaction term $\mathrm{pH}-\mathrm{T}$ in equations 1 and 2 highlights the cross effect of $\mathrm{pH}$ and temperature on stability. Negative coefficients of $\mathrm{T}$ indicate a negative effect of high temperatures on activity.

The enzyme was more stable at $\mathrm{pH} 11$, confirming that the obtained enzyme was an alkaline protease. Although a thermophilic enzyme was expected, the best results for thermal stability were obtained at $43.8^{\circ} \mathrm{C}$ for $\mathrm{F}$ and $30^{\circ} \mathrm{C}$ for $\mathrm{FC}$ samples $(37 \%$ and $51 \%$ residual activity at optimal conditions, respectively).

\section{Conclusions}

The soy fibre residues were a suitable source for alkaline protease production by SSF. The results reveal that high yield can be obtained without inoculating any specific microorganism, suggesting that the SSF process could be scalable. This enzyme is more stable at alkaline $\mathrm{pH}$ and mesophilic temperatures and can be preserved for at least three 
months by freezing at $-80^{\circ} \mathrm{C}$. Further studies are necessary to confirm the possible uses of this alkaline protease and its full characterisation.

\section{Acknowledgements}

The authors thank the Spanish Ministerio de Economía y Competitividad (Project CTM2012-33663) for their financial support. J. Abraham thanks the UAB for their financial support. 


\section{References}

[1] A. Pandey, Solid-state fermentation, Biochem. Eng. J. 13 (2003) 81-84.

[2] A. Pandey, P. Selvakumar, C.R. Soccol, P. Nigam, Solid-state fermentation for the production of industrial enzymes, Curr. Sci. 77 (1999) 149-162.

[3] R.R. Singhania, A.K. Patel, C.R. Soccol, A. Pandey, Recent advances in solid-state fermentation, Biochem. Eng. J. 44 (2009) 13-18.

[4] N.G. Edwinoliver, K. Thirunavukarasu, R.B. Naidu, M.K. Gowthaman, T. Nakajima Kambe, N.R. Kamini, Scale up of a novel tri-substrate fermentation for enhanced production of Aspergillus niger lipase for tallow hydrolysis, Bioresource Technol. 101 (2010) 6791-6796.

[5] M. Muller dos Santos, A. Souza da Rosa, S. Dal'Boit, D.A. Mitchell, N. Krieger, Thermal denaturation: is solid-state fermentation a good technology for the production of enzymes? Bioresource Technol. 93 (2004) 261-268.

[6] A. Santis-Navarro, T. Gea, R. Barrena, A. Sánchez, Production of lipases by solidstate fermentation using vegetable oil-refining wastes, Bioresouce Technol. 102 (2011) 10080-10084.

[7] A.K. Mukherjee, H. Adhikari, K.R. Sudhir, Production of alkaline protease by thermophilic Bacillus subtilis under solid-state fermentation (SSF) condition using Imperata cylindrica grass and potato peel as low-cost medium: Characterization and application of enzyme in detergent formulation, Biochem. Eng. J. 39 (2008) 353-361.

[8] W. Han, M. He, Short-term effects of exogenous protease application on soil fertility with rice straw incorporation, Eur. J. Soil Biol. 46 (2010) 144-150.

[9] L. Ruggieri, T. Gea, A. Artola, A. Sánchez, Air filled porosity measurements by air pycnometry in the composting process: A review and a correlation analysis, Bioresource Technol. 100 (2009) 2655-2666. 
[10] R. Barrena, E. Pagans, A. Artola, F. Vazquez, A. Sanchez, Co-composting of waste from the tanning industry with de-inking and municipal wastewater sludges, Biodegradation 18 (2007) 257-268.

[11] R. Barrena, J. Turet, A. Busquets, M. Farrés, X. Font, A. Sánchez, Respirometric screening of several types of manure and mixtures intended for composting, Bioresource Technol. 102 (2011) 1367-1377.

[12] S. Ponsá, T. Gea, A. Sánchez, Different indices to express biodegradability in organic solid wastes, J. Environ. Qual. 39 (2010) 706-712.

[13] B. Puyuelo, T. Gea, A. Sánchez, A new control strategy for the composting process based on the oxygen uptake rate, Chem. Eng. J. 165 (2010) 161-169.

[14] K. Alef, P. Nannipieri, Methods in Applied Soil Microbiology and Biochemistry, Academic Press Limited, San Diego, 1995.

[15] The US Department of Agriculture and The US Composting Council, Test Methods for the Examination of Composting and Compost, Edaphos International, Houston, 2001.

[16] S. Ponsà, B. Puyuelo, T. Gea, A. Sanchez, Determining C/N ratios for typical organic wastes using biodegradable fractions, Chemosphere. 85 (2011) 653-659.

[17] B.L. Fetuga, G.M. Babatunde, V.A. Oyenuga, 1974. Protein quality of some unusual protein foodstufs: studies on the African locust-bean seed (Parkia Wlicoidea Welw.). Br. J. Nutr. 32, 27-36.

[18] F. Uyar, Z. Baysal, Production and optimization of process parameters for alkaline protease production by a newly isolated Bacillus sp. under solid-state fermentation, Process Biochem. 39 (2004) 1893-1898. 
[19] N. Mahanta, A. Gupta, S.K. Khare, Production of protease and lipase by solvent tolerant Pseudomonas aeruginosa PseA in solid-state fermentation using Jatropha curcas seed cake as substrate, Bioresource Technol. 99 (2008) 1729-1735.

[20] C.J.S.M. Silva, Q. Zhang, J. Shen, A. Cavaco-Paulo, Immobilization of proteases with a water soluble-insoluble reversible polymer for treatment of wool, Enzyme Microb. Technol. 39 (2006) 634-640. 


\section{Figure captions}

Figure 1. Experimental set-up of the bench-scale solid-state fermentation reactor.

Figure 2. Solid-state fermentation profiles (one replicate is shown): a) soy fibre, b) soy fibre with $10 \%$ compost. Temperature ( - , solid line), oxygen content in exhaust gases $(\cdots$, dotted line), $\mathrm{pH}(\boldsymbol{\Delta})$ and protease $(\diamond)$.

Figure 3. Response surface for residual activity in stability assays: a) soy fibre, b) soy fibre with $10 \%$ compost. 
Figure 1

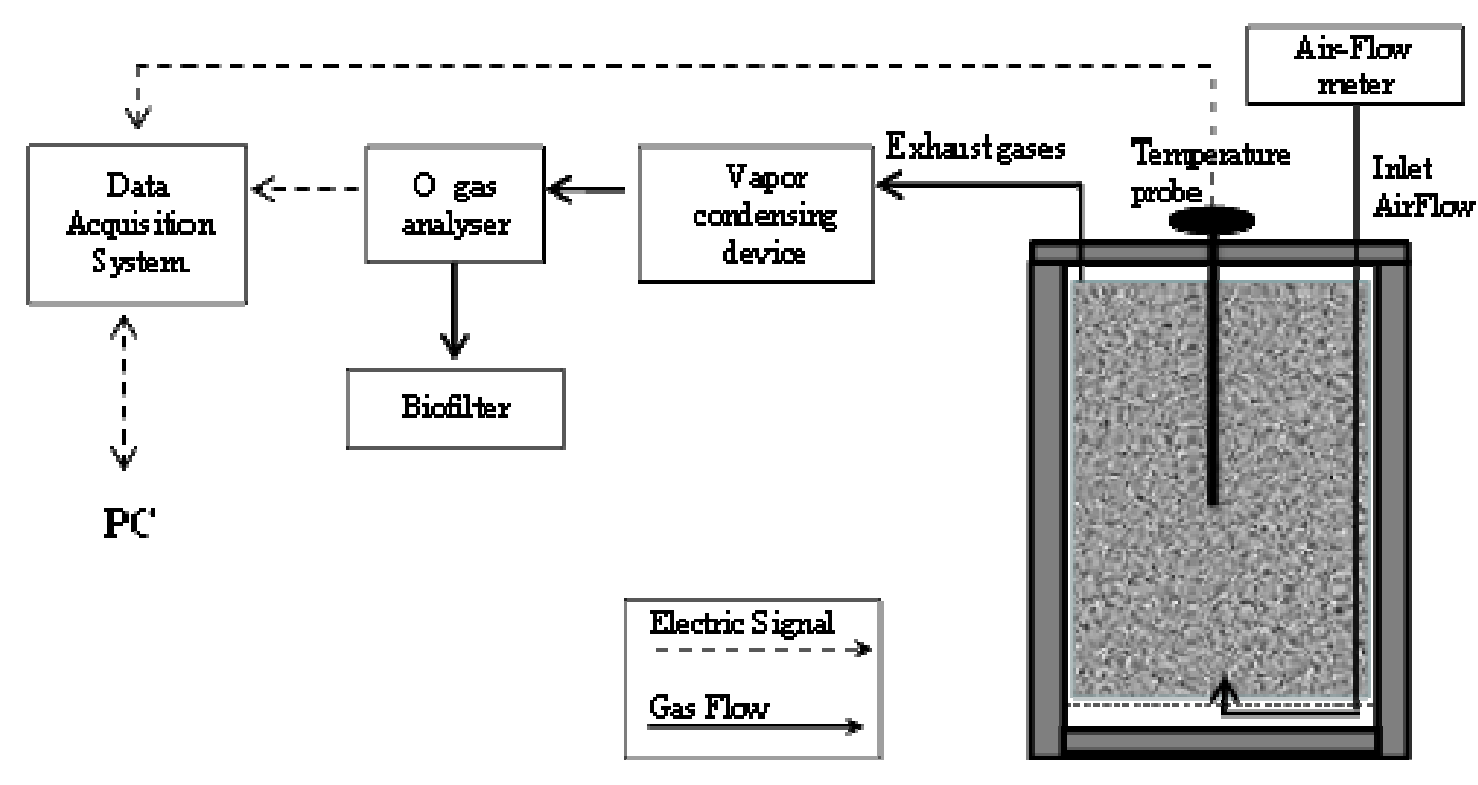


Figure 2

a)

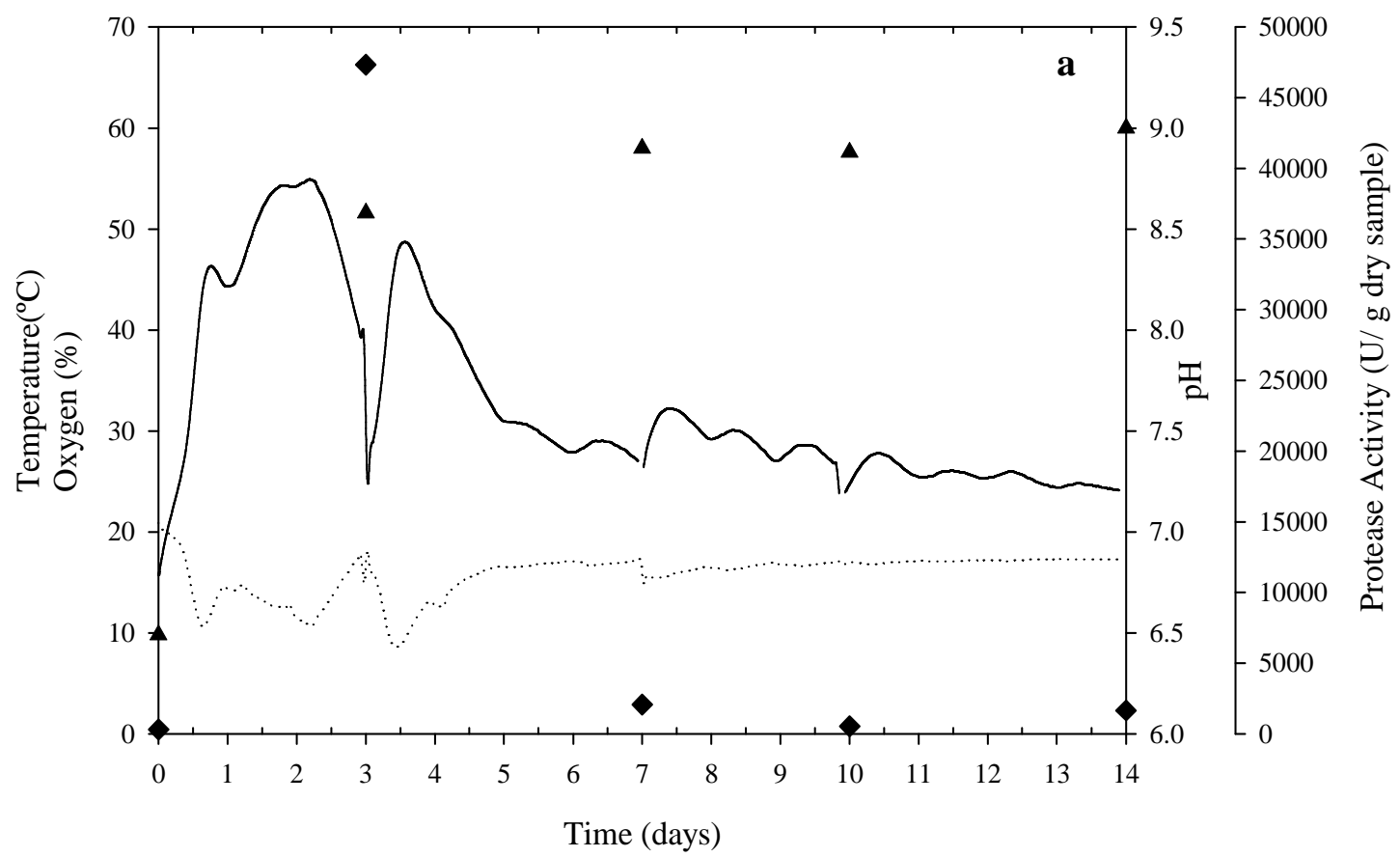

b)

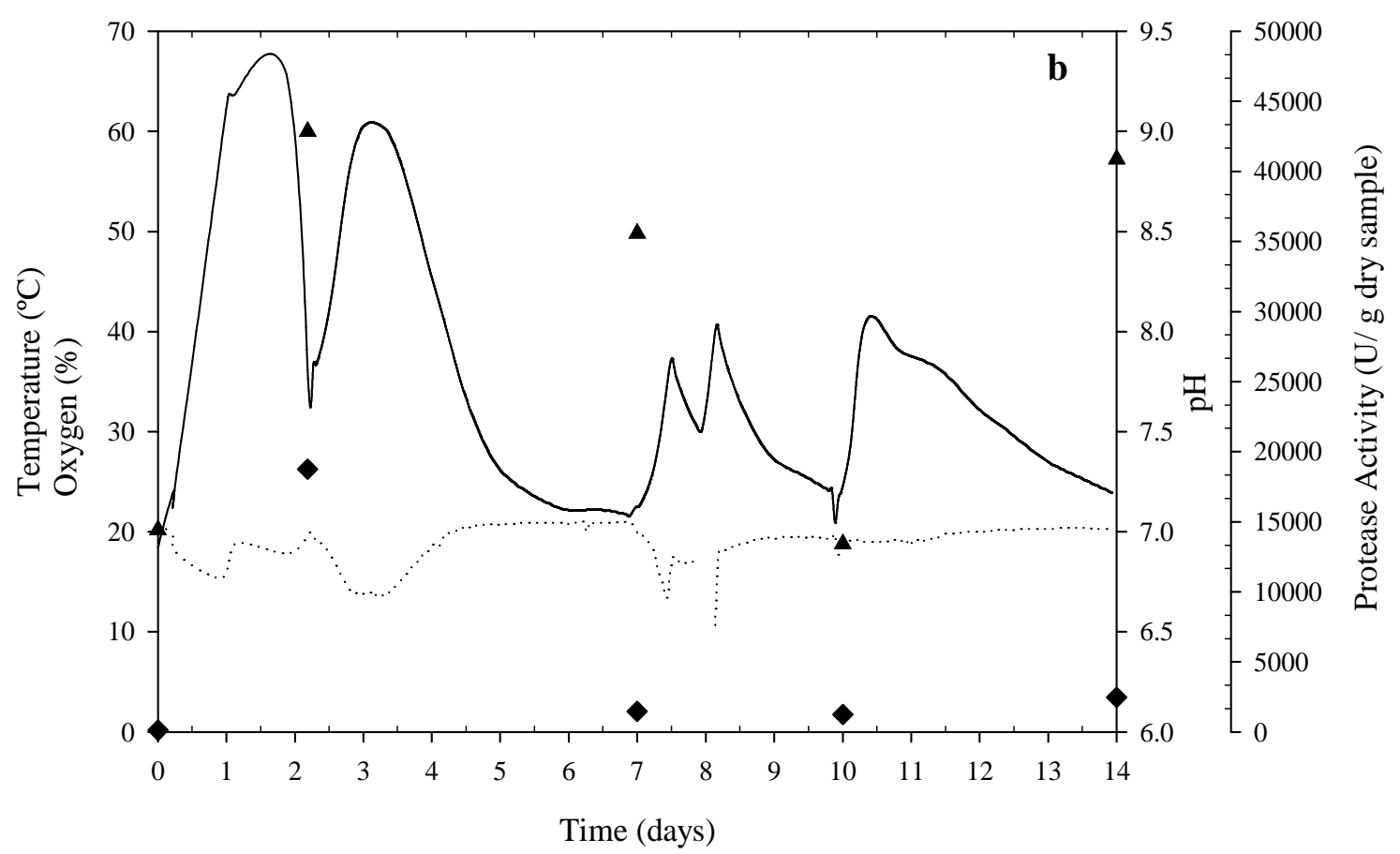


Figure 3
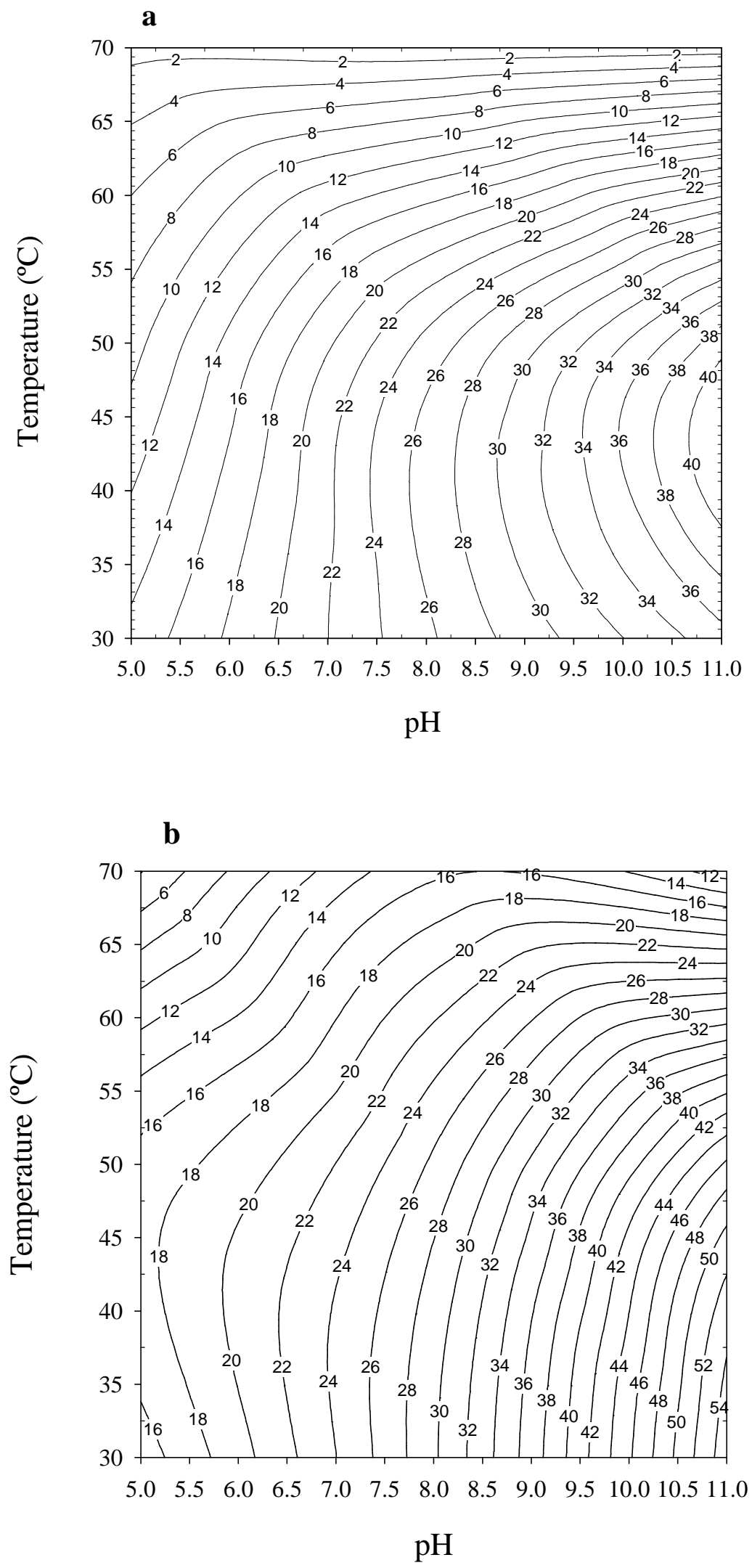


\section{Tables}

Table 1. Characterisation of the wastes used in the study.

\begin{tabular}{|c|c|c|c|}
\hline Waste & Hair waste & Soy fibre & Coffee husk \\
\hline Water content $(\%, \mathrm{db})$ & $59.9 \pm 0.4$ & $82.5 \pm 1.2$ & $79.4 \pm 0.3$ \\
\hline Organic matter $(\%, \mathrm{db})$ & $86.0 \pm 0.1$ & $97.7 \pm 0.5$ & $92.2 \pm 0.2$ \\
\hline $\mathrm{pH}$ & $10.76 \pm 0.01$ & $7.37 \pm 0.01$ & $7.49 \pm 0.01$ \\
\hline $\mathrm{EC}\left(\mu \mathrm{S} \mathrm{cm}{ }^{-1}\right)$ & $5.03 \pm 0.01$ & $0.70 \pm 0.01$ & $1.26 \pm 0.01$ \\
\hline $\begin{array}{l}\text { Dynamic respiration index } \\
\left(\mathrm{g} \mathrm{O}_{2} \mathrm{~kg}^{-1} \mathrm{DM} \mathrm{h}^{-1}\right)\end{array}$ & $3.0 \pm 0.4^{*}$ & $5.6 \pm 0.8$ & $3.0 \pm 0.3$ \\
\hline Total Organic Carbon (\% db) & $57.2 \pm 0.9$ & $67.5 \pm 0.9$ & $67.4 \pm 0.1$ \\
\hline Total Nitrogen Kjeldhal (\% db) & $12.0 \pm 0.1$ & $4.4 \pm 0.2$ & $2.7 \pm 0.2$ \\
\hline $\mathrm{C} / \mathrm{N}$ ratio & 4.8 & 15.4 & 24.8 \\
\hline
\end{tabular}

Abbreviations: EC: electrical conductivity, wb: wet basis, db: dry basis, DM: dry matter.

* Ratio 1:2 hair waste:raw sludge. 